DOI: https://doi.org/10.25217/jf.v4i1.441 http://journal.iaimnumetrolampung.ac.id/index.php/jf

\title{
KONSTRUKSI IDEOLOGIS ISLAM MODERAT DI LINGKUNGAN KAMPUS: STUDI KASUS MA'HAD AL-JAMI'AHUIN SUNAN AMPEL SURABAYA DAN UIN MAULANA MALIK IBRAHIM MALANG
}

\author{
Haris Shofiyuddin ${ }^{1}$ \\ ${ }^{I}$ Universitas Islam Negeri Sunan Ampel, Surabaya \\ * CORRESPONDENCE: $\triangle$ harisshofiyuddin@gmail.com
}

\begin{abstract}
Abstrak
The purpose of this article is to find out the position and role of Ma'had alJami'ah at The State Islamic University of Sunan Ampel Surabaya and The State Islamic University of Maulana Malik Ibrahim Malang in strengthening the importance of Moderate Islam. In the context of this goal, this paper is expected to contribute to formulating a philosophical frame of mind and its application of Ma'had al-Jämi'ah's strategic position as an institution that takes part in strengthening the ideology of Moderate Islam. Practically, this research can be a basis and guideline for all campus stakeholders, both at the State Islamic University of Sunan Ampel Surabaya and the State Islamic University of Maulana Malik Ibrahim Malang, or other campuses regarding the importance of Ma'had al-Jämi'ah as a guarded front in supporting the mainstreaming of moderate Islam in the campus environment. In reviewing this matter, researchers used a type of qualitative research with a phenomenological approach. The results of this study are Ma'had al-Jämi'ah has played a role in strengthening the ideology of Moderate Islam on campus reflected in daily activities. These activities aim as habituation and also as a strategy, exemplary, and also fosters discipline and build a tolerant character. Besides that there are several activities to realize moderate Muslim attitudes in Ma'had al-Jāmi'ah, cultural tolerance through fostering tolerant student life, understanding cultural diversity and moreover gaining human nature regardless of social or economic status.
\end{abstract}

Tujuan dari artikel ini adalah untuk mengetahui posisi dan peran Ma'had alJāmi'ah UIN Sunan Ampel Surabaya dan UIN Maulana Malik Ibrahim Malang dalam memperkuat pentingnya Islam Moderat. Dalam konteks tujuan ini, tulisan ini diharapkan dapat berkontribusi dalam merumuskan kerangka berpikir filosofis dan penerapannya tentang posisi strategis Ma'had al-Jāmi'ah sebagai lembaga yang mengambil bagian dalam memperkuat ideologi Islam Moderat. Secara Praktis, penelitian ini dapat menjadi pijakan dan pedoman bagi semua pemangku kepentingan kampus, baik di Universitas Islam Negeri Sunan Ampel Surabaya dan Universitas Islam Negeri Maulana Malik Ibrahim Malang, atau kampus lain mengenai pentingnya Ma'had al-Jämi'ah sebagai penjaga depan dalam mendukung pengarusutamaan Islam moderat di lingkungan kampus. Dalam mengkaji hal tersebut peneliti menggunakan jenis penelitian kualitatif dengan pendekatan fenomenologi. Adapun hasil dari penelitian ini adalah Ma'had al-Jämi'ah berperan dalam memperkuat ideologi Islam Moderat di kampus yang tercermin dalam kegiatan sehari-hari. Kegiatan ini bertujuan sebagai pembiasaan dan juga sebagai strategi, keteladanan, dan juga menumbuhkan disiplin dan membangun karakter yang toleran. Selain itu ada beberapa kegiatan untuk mewujudkan sikap Muslim moderat di Ma'had alJāmi'ah toleransi budaya melalui menumbuhkan kehidupan mahasiswa yang toleran, memahami keragaman budaya dan juga memahami sifat manusia terlepas dari status sosial atau ekonomi.

\section{Article Info}

\section{Article History}

Received : 30-03- 2019,

Revised : 13-06-2019,

Accepted : 13-06-2019

\section{Keywords:}

Role ;

Islam Moderate ;

Mainstreaming ;

Ma'had al-Jāmi'ah

\section{Histori Artikel}

Diterima :30-03-2019

Direvisi : :13-06-2019

Disetujui :13-06-2019

\section{Kata Kunci:}

Peran;

Islam Moderat;

Pengarusutamaan;

Ma'had al-Jāmi'ah; 


\section{A. Pendahuluan}

Satu hal yang menjadi tantangan besar Islam di Indonesia era kekinian adalah maraknya kelompok Islam transnasional yang selalu menggerak mengembangkan ideologinya secara bebas kepada masyarakat. ${ }^{1}$ Pasalnya, dikatakan tantangan sebab ideologi yang mereka yakini dan digerakkan sangat jauh -bahkan cenderung bertentangan- dengan semangat kebangsaan dan keagamaan yang telah lama diwariskan oleh para pendiri bangsa (the founding fathers), yang selalu mengedepankan semangat moderat dan toleransi dalam merespon kehidupan sosial dan budaya sebagaimana tergambarkan -misalnya — dalam nilai-nilai Pancasila yang menjadi dasar ideologi dalam kehidupan berbangsa dan bernegara. ${ }^{2}$

Kondisi ini yang kemudian menjadikan kontestasi ideologis antar kelompok Islam tidak bisa dihindarkan, bahkan kontestasi ini bila dibiarkan akan mengancam Nahdlatul Ulama' dan Muhammadiyah yang sejak lama mengembangan nilai-nilai moderat Islam sebab kelompok transnasional sangat masif bergerak melakukan indoktrinisasi ideologi islamisme, bahkan dengan serius dalam situasi tertentu merebut institusi-institusi sosial yang dimiliki oleh kedua kelompok Islam terbesar ini, misalnya dengan menguasai masjid dan institusi pendidikan. ${ }^{3}$ Termasuk, indoktrinisasi ideologi transnasional dilakukan di kampus-kampus dengan mewacanakan pentingnya penerapan syariah Islam dan khilafah Islamiyah, sambil berteriak menolak Pancasila sebagai dasar ideologi berbangsa dan bernegara serta menolak sistem demokrasi karena lahir dari tradisi Barat.

Secara khusus, fenomena dakwah Islam model gerakan Islam Tranasional di kampus menjadi sangat menarik, sebab kampus tidak lagi menjadi persemaian untuk menguatkan intelektual kritis, tapi juga menjadi medan kontestasi ideologi, khususnya kontestasi antara arus Islam Moderat dengan Islam transnasional dengan segala karakternya; tekstualis, skriptualis, dan fundamentalis. Atas semangat dakwah Islam, mereka merebut masjid-masjid kampus dan merebut organisasi pembinaan keagamaan di kampus.

Tentang hal ini, menarik ulasan M. Imdadun Rahmat tentang perkembangan indoktrinisasi ideologis atas nama dakwah Islam di lingkungan kampus. Masjid Salman ITB, misalnya, adalah contoh riil bagaimana indoktrinasi ideologis itu berjalan pelan tapi pasti dengan melibatkan jaringan Lembaga Dakwah Kampus (LDK). Berbagai kampus akhirnya menjadi sasarannya, dengan banyak melibatkan para mentor-mentor alumni masjid Salman atau mentor yang berjejaring dengannya.

\footnotetext{
${ }^{1}$ Maraknya gerakan Islam Transnasional disinyalir dimulai pasca lahirnya era reformasi. Hal ini terjadi disebabkan era ini adalah era proses transisi dari sistem otoriter ke sistem demokrasi. Jika dalam sistem otoriter memungkinkan sulit berkembang kelompok-kelompok Islam yang secara ideologi bertentangan dengan pemerintah.Berbeda dengan sistem demokrasi, dimana kebebasan berpendapat sangat dijunjung tinggi. Euforia kebebasan berpendapat atas nama demokrasi ini menjadi pemantik suburnya kelompok-kelompok Islam Transnasional berkembang masuk di berbagai tempat. Baca tentang ini, Nurrohman dan Marzuki Wahid, "Politik Formalisasi Syari'at Islam dan Fundamentalisme Islam”, dalam Jurnal Penelitian Direktorat Perguruan Tinggi Agama Islam, Istiqro', Vol. 01, No. 01, 2002, 45; Jamhari dan Jajang Jahroni, Gerakan Salafi Radikal di Indonesia (Jakarta: Rajawali Press, 2004)., As'ad Said Ali, Ideologi Gerakan Paska Reformasi(Jakarta: LP3ES, 2013).

2 Muhamad Agus Mushodiq et al., "Kristalisasi Ideologi Islam Nusantara Melalui Pembelajaran Dan Pengadaan Kaligrafi," Fikri: Jurnal Kajian Agama, Sosial Dan Budaya 3, no. 1 (July 31, 2018): 143-72, https://doi.org/10.25217/jf.v3i1.281.

${ }^{3}$ Dengan dasar ini NU -khususnya- melakukan perlawanan dengan melakukan labelisasi NU terhadap institusi sosial, pendidikan, rumah sakit dan lain-lain.Lihat sikap tegas KH.Hasyim Muzadi, ketika masih menjabat Ketua Umum PBNU di http://www.nu.or.id/post/read/9124/ atau https://nasional.sindonews.com/read/1189843/18/hasyimmuzadi-dan-fleksibilitas-islam-1489973140.Di akses 20 April 2018.
} 
Sebut saja misalnya, UI, IPB, ${ }^{4}$ UGM, UNAIR Surabaya, ITS Surabaya, UNDIP Semarang, USU Medan, dan UNHAS Makassar. Bukan hanya itu, dakwah-dakwah kampus model indoktrinisasi ideologis masuk ke jantung insitusi pendidikan Islam, misalnya IAIN dan perguruan tinggi swasta yang menjadi basis intelektual kalangan pesantren. ${ }^{5}$

Oleh sebab itu, pembiaran terhadap model dakwah kampus yang berujung pada kaderisasi mahasiswa anti Pancasila dan demokrasi sangat berbahaya, bukan saja bagi institusi kampus itu sendiri, tapi juga bagi proses kehidupan berbangsa dan bernegara di Indonesia, mengingat para mahasiswa yang telah dikader kelak akan menjadi alumni dan hidup dalam lingkungan masyarakat luas. Pastinya, mereka akan setia terhadap keyakinan ideologis yang diperoleh di kampus sehingga ikut terlibat menyebarkan dan melakukan indoktrinasi kepada orang lain, kecuali mereka yang dalam perjalanannya tercerahkan kembali ke khittah Islam moderat rahmat li al-'Alamin dan tetap setia pada nilai Pancasila. ${ }^{6}$

Sebagai bagian dari institusi kampus Islam, UIN Sunan Ampel Surabaya dan UIN Maulana Malik Ibrahim Malang harus terus berkomitmen membangun jalan terang penuh hikmah bagi penumbuhan basis intelektual Muslim yang secara ideologis setia bagi bangsa dan negara. Jalan terang ini adalah keniscayaan sebab kedua merupakan institusi pendidikan tinggi yang berada di bawah pembinaan Kementerian Agama Republik Indonesia (Kemenag RI), khususnya direktorat pendidikan Islam. Dalam konteks ideologis, komitmen Kemenag RI dilihat dari visi dan misinya sama persis dengan ideologi yang dianut bangsa ini, khususnya dalam bidang keagamaan. Sebut saja misalnya, salah satu visi dan misi itu menyebutkan bahwa tujuan pembangunan kementerian agama adalah: "Peningkatan kualitas pemahaman dan pengamalan ajaran agama dalam rangka meningkatkan kualitas kehidupan beragama.Pengukuhan suasana kerukunan hidup umat beragama yang harmonis sebagai salah satu pilar kerukunan nasional.",7

Kutipan ini dapat dipahami bahwa Kementerian Agama selalu bergerak dalam semangat nilai Islam Moderat untuk menuju keharmonian umat.Semua kegiatan instituasi yang memiliki kaitan dengan Kemenag, baik langsung atau tidak, harus berkait dengan terwujudnya semangat sebagaimana disebutkan dalam visi dan misinya.Jika tidak, maka lembaga itu harus diberikan pembinaan sebab berkhianat pada institusinya sendiri, termasuk berkhianat kepada bangsa dan negara.

Tapi, memang fakta sosiologis tidak bisa dipungkiri -dan dianggap ringan-sejak UIN Sunan Ampel dan UIN Maulana Malik Ibrahim beralih fungsi, yang dulunya sama-sama sebagai IAIN, dengan semangat integrasi keilmuannya ${ }^{8}$ memastikan input mahasiswa sangat beragam; mulai

${ }^{4}$ Forum-forum dakwah Islam melalui Lembaga Kegiatan Dakwah (LKD) atau dengan nama yang berbeda menjadi jalan bagi lahirnya gerakan Tarbiyah, bahkan menjadi cikal bakal lahirnya Hizbut Tahrir Indonesia (HTI); sebuah organisasi Islam transnasional, yang secara ideologis terang-terang menolak Pancasila dan sistem demokrasi dengan tawaran alternatif gerakannya pembentukan khilafah Islamiyah. Lihat Ainur Rafiq al-Amin, Proyek Khilafah, Perspektif Kritis (Yogyakarta: LKiS, 20015).

${ }^{5}$ M. Imdadun Rahmat, Ideologi Politik PKS: Dari Masjid Kampus Ke Gedung Parlemen, Cet. 1 (Yogyakarta: LKiS : distribusi, LKiS Pelangi Aksara Yogyakarta, 2008), 67.

${ }^{6}$ Habib Ismail and Agus Setiawan, "Pemberdayaan Pondok Pesantren Nahdlatul Ulama (NU) Dalam Upaya Deradikalisme Paham Dan Gerakan Islam Radikal Di Kota Metro," Fikri : Jurnal Kajian Agama, Sosial Dan Budaya 3, no. 1 (July 31, 2018): 173-92, https://doi.org/10.25217/jf.v3i1.282.

${ }^{7}$ Lengkapnya tentang visi dan misi ini lihat web Kemenag, https://kemenag.go.id/home/artikel/42942. Diakses tanggal 20 April 218.

${ }^{8}$ Catatan Husniyatus Salamah Zainiyati menarik soal landasan fondasional dari dua kampus ini dalam menguatkan proses integrasi keilmuan di kampus. Hasilnya, salah satunya, bahwa kedua kampus ini sama-sama memandang penting adanya asrama kampus, meskipun dalam penamaannya yang berbeda. Lihat, Husniyah Salamah 
alumni pesantren, Aliyah Negeri dan swasta hingga umum. Keragaman ini yang kemudian pemahaman dan kemampuan keagaman mereka juga beragam, khususnya fakultas umum hampir mayoritas mahasiswanya adalah alumni umum.Dengan begitu, tantangan kedua kampus ini sangat kompleks dalam mengawal nilai-nilai keislaman dalam praktik kehidupan mahasiswa agar tidak terkontaminasi oleh paham-paham yang bertentangan dengan nilai-nilai Islam moderat yang menjadi arus utama kedua kampus ini.

Bukan hanya itu, calon mahasiswa yang datang ke kampus dari berbagai daerah diyakini akan mengalami shock culture di tengah kompleksitas kehidupan perkotaan di dua kampus ini, yakni kota Surabaya dan Malang. Kondisi ini perlu menjadi perhatian serius juga agar mahasiswa tidak mudah mengalami kebimbangan psikologis sehingga mudah meniru prilaku masyarakat perkotaan, tanpa melakukan penguatan dan pertahanan terhadap tradisi baik yang telah diperoleh sebelumnya. Belum lagi, mahasiswa yang masuk berasal dari luar negeri dengan segala karakternya yang berbeda.

Karenanya, untuk memperkuat pondasi integrasi keilmuan, kedua kampus ini sejak dini mengantisipasi perlunya pembinaan intensif mahasiswa dengan semangat tradisi kepesantrenan. Maksudnya, ada upaya penanaman ideologi dengan bentuk konstruksi nilai secara intensif kepada mahasiswa agar memiliki kematangan secara menyeluruh, yakni kematangan intelektual-akademik di satu sisi dan kematangan spiritual berbasis akhlak karimah di sisi yang berbeda.Upaya ini sangat beralasan, agar mahasiswa tidak hilang jati-dirinya sebagai Muslim, sekaligus sebagai bagian dari anak bangsa yang harus tetap berkomitmen menjaga nilai-nilai kebangsaan dalam bingkai kebinekaan.

Salah satu jalan agar keinginan ini terwujud dengan baik adalah adanya kesadaran menyeluruh dari insan kampus untuk menjadikan prinsip Islam moderat sebagai pondasi bergerak. Pengarusutamaan Islam moderat diharapkan mahasiswa di kampus sejak dini telah dikenalkan tentang nilainilai normatif Islam, yang mengajarkan tentang pentingnya menjaga harmoni dalam keragaman bangsa. Di samping, tetap konsisten pada pokok ajaran yang bersifat individual (vertikal). Dasar pijak pikiran ini yang memantik tulisan ini perlu dilakukan dengan tema "Konstruksi Ideologis dan Peran Ma'had al-Jami'ah dalam Menguatkan Pengarus-utamaan Islam Moderat di Lingkungan Kampus: Studi Kasus UIN Sunan Ampel Surabaya dan UIN Maulana Malik Ibrahim Malang”.

Setelah melakukan penelusuran secara seksama, rancangan penelitian belum pernah dibahas sebelumnya sehingga dipandang penting untuk diteruskan. Memang ada beberapa penelitian yang berhubungan, tapi lebih bersifat serpihan perbincangan belum menyeluruh mengungkap soal maksud penelitian ini, yang lebih fokus pada upaya menemukan model konstruksi lembaga tinggi Islam dalam menguatkan nilai-nilai moderat di kampus, tepatnya UIN Sunan Ampel dan UIN Maulana Malik Ibrahim. Beberapa tulisan dan penelitian memiliki keterkaitan di antaranya:

Penelitian Husniyah Salamah Zainiyati tentang Landasan Fondasional Integrasi Keilmuan di UIN Maulana Malik Ibrahim Malang dan UIN Sunan Ampel Surabaya. Menarik dari penelitian Zainiyati adalah pelibatan dua lembaga pendidikan Islam yang sama dengan rancangan penelitian ini. Salah satu temuan yang dihasilkan adalah bahwa kedua kampus ini memandang penting terhadap perkuliahan non-reguler model pengasramaan pesantren untuk menopang perguliahan regular.Kedua perkuliahan ini penting bersifat komplemen untuk menjaga semangat integrasi

Zainiyati, "Landasan Fondasional Integrasi Keilmuan di UIN Maulana Malik Ibrahim dan UIN Sunan Ampel Surabaya ”, dalam Jurnal LP2M UIN Sunan Ampel Surabaya, Penelitian Ilmu-Ilmu Keislaman, Vol. 19, No. 2, 2016, $249-277$. 
keilmuan yang berkelindan dalam gerak keilmuan agama dan umum.Tapi memang, penelitian Zainiyati tidak mengungkap model pengarusutamaan Islam moderat di kampus dengan melibatkan Ma'had al-Jami'ah sebagai ujung tombak sebagaimana tujuan penelitian ini.

Berbeda dengan Zainiyati, tulisan Maimunah yang berjudul Kepemimpinan Pembelajaran di Pondok Pesantren (Studi Kasus di Ma'had al-Jami'ah IAIN Ambon). Perbedaannya, terletak bahwa Maimunah lebih fokus pada konteks Ma'had al-Jami'ah sekalipun hanya terbatas di IAIN Ambon dalam bingkai kepemimpinan pembelajaran.Temuannya, bahwa kepemimpinan pembelajaran di Ma'had al-Jami'ah berbentuk kepemimpinan birokratik sebab semua keputusan selalu berkaitan dengan kebijakan kampus. Untuk itu, tulisan ini tidak ada kaitan dengan penelitian yang dirancang, tapi setidaknya memberikan gambaran bahwa keberadaan pesantren mahasiswa (Ma'had alJami'ah) di lingkungan kampus sangat strategis ikut mengawal visi dan misi kampus sehingga keputusan selalu mengikuti irama pusat (rektorat).

Tulisan lain yang hampir sama, mengulas kontestasi ideologi Islam Transnasional di kampus adalah tulisan Sahri yang berjudul Radikalisme Islam di Perguruan Tinggi Perspektif Islam. ${ }^{9}$ Sahri mampu mengungkap sebab musabab bagaimana radikalisme itu tumbuh dalam lingkungan kampus sejak IAIN beralih fungsi ke UIN. Salah satunya, para mahasiswa yang berasal dari lulusan SMA/SMK/STM, lantas masuk dunia kampus mereka menemukan ghirah keislaman melalui keterlibatannya dengan kelompok jejaring organisasi dakwah kampus hingga mengantarkan mereka terjebak dalam nalar berpikir dan bertindak radikal, setidaknya larut dalam diskusi-diskusi ideologi model Islam transnasional, seperti penerapan Syari'at Islam, Khilafah Islamiyah, dan lain-lain, yang secara prinsip jauh dengan semangat Islam moderat sebagaimana menjadi fokus penelitian ini. Tulisan Sahri cukup membantu rancangan penelitian ini kaitan kontestasi ideologi di kampus

Berdasarkan tulisan-tulisan di atas sebagai landasan penelitian dahulu, maka penelitian ini masih dipandang signifikan sebab mengisi kekosongan bahasan yang tidak diulas dalam tulisan tersebut. Mengingat, kajian penelitian ini lebih fokus pada bahasan konstruksi ideologis dan peran Ma'had al-Jämi'ah dalam proses pengarusutamaan Islam moderat di kampus, khususnya kampus UIN Sunan Ampel dan UIN Maulana Malik Ibrahim. Tapi, tulisan-tulisan yang telah disebutkan ikut membantu peneliti dalam mengungkap seluk-beluk kontestasi ideologi dalam dunia kampus hingga melahirkan radikalisme dan fundamentalisme Islam sebagai lawan dari Islam moderat.

\section{B. Metode Penelitian}

Jenis penelitian yang digunakan dalam artikel ini adalah kualitatif. Dengan berpijak pada karakternya, yang tidak berkaitan dengan analisis berbasis angka, memastikan penelitian ini berusaha membaca tindakan dan maknanya dari kedua lembaga, yakni Ma'had al-Jämi'ah UIN Sunan Ampel Surabaya dan Ma'had al-Jāmi'ah UIN Maulana Malik Ibrahim Malang dalam mengkonstruksi pengasurus-utamaan Islam moderat di kampus. Artinya, penelitian ini lebih fokus pada tindakan sosiologis serta makna dibalik tindakan yang dilakukan kedua lembaga ini dalam mengkonstruksi nilai-nilai Islam moderat dalam lingkungan kampus melalui Ma'had al-Jāmi'ah sebab sebuah tindakan tidak datang tiba-tiba, tapi memiliki motif dan konsekuensi yang diakibatkan. ${ }^{10}$

${ }^{9}$ Sahri, "Radikalisme Islam di Perguruan Tinggi Perspektif Islam” dalam jurnal Hukum dan Perundangan Islam; al-Daulah, Volume 6, Nomor 1, April 2016, 235-268.

${ }^{10}$ Dalam ilmu sosial, model seperti ini masuk pada kategori penelitian fenomenologi. Weber adalah salah satu tokoh penting dalan mengembangkan penelitian model ini melalui gagasannya in order to motive. Lantas Schult 
Untuk melengkapi data penelitian ini, peneliti menggunakan tiga pola penggalian data secara bersamaan agar terjadi saling melengkapi, yakni wawancara mendalam (in-depth interview), pengamatan lapangan (fieldnotes) dan dokumentasi. ${ }^{11}$ Untuk memastikan tingkat kepercayaan dan otentisisi instrument, penulis menggunakan proses trianggulasi, agar data yang diperoleh benarbenar sesuai dengan maksud penelitian ini, sekaligus bedasarkan fakta sebenarnya.

Prosesnya, peneliti melakukan penggalian data dengan wawancara kepada stake holder Ma'had al-Jämi'ah, baik UIN Sunan Ampel maupun UIN Maulana Malik Ibrahim. Di samping itu, peneliti juga akan melakukan wawancara dengan pihak-pihak yang terkait, misalnya mahasiswa sebagai pengguna manfaat, untuk memastikan temuan model kedua Ma'had al-Jāmi'ah melakukan konstruksi nilai dalam pengarus-utamaan Islam moderat sebab kedua lembaga ini dipastikan memiliki pola yang khusus, berdasarkan kondisi sosiologis dan budaya kaitannya kontestasi ideologi yang dihadapi, khususnya menyikapi maraknya ideologisasi Islam Radikal dalam lingkungan kampus.

Setelah itu, peneliti menuliskan hasil temuan di lapangan secara runtut kaitan pengarus-utamaan Islam moderat yang dilakukan Ma'had al-Jämi'ah di kampus. Pastinya, penulisan data dilakukan secara teliti dengan proses pembandingan data dan mengkaji ulang agar temuan yang di lapangan benar-benar otentik bukan perkiraan semata. Langkah ini juga diharapkan, peneliti dapat menyuguhkan gambaran data kaitan model pengarus-utamaan Ma'had al-Jämi'ah dalam menguatkan Islam Moderat di kampus, terkhusus mengungkap persamaan dan perbedaan yang dilakukan oleh UIN Sunan Ampel dan UIN Maulana Malik Ibrahim.

Setelah peneliti mengumpulkan data, maka langkah penelitian selanjutnya adalah analisis data.Aktivitas pengumpulan, penulisan data, dan analisis data adalah aktivitas penelitian yang harus dilakukan secara bersamaan. Oleh karenanya, peneliti menggunakan pola yang ditawarkan oleh Miles dan Huberman dengan memperhatikan tiga tahapan analisis, yaitu reduksi data (data reduction), penyajian data (data display) dan pengumpulan atau verifikasi (Conclusion Drawing/Verification). baik ketika atau sesudah pengumpulan data penelitian. Tiga tahapan ini akan menjadi landasan peneliti dalam mengupas tentang kontruksi ideologis dan peran Ma'had Jämi'ah dalam pengarustaan Islam moderat di kampus berdasarkan data-data yang ditemukan dilapangan, yakni kampus UIN Sunan Ampel dan UIN Maulana Malik Ibrahim.

Sambil menganalisis data, peneliti juga melalukan interpretasi data, baik data dokumentasi, wawancara dam temuan di lapangan. Interpretasi ini diharapkan dapat membantu peneliti dalam mengungkap pola dan tindakan kampus, yakni Ma'had al-Jämi'ah, termasuk makna dibalik pilihanpilihannya dalam pengarusutamaan Islam moderat di kampus dengan menggunakan pola teoritis yang berkembang dalam penelitian berbasis fenomenologis, tepatnya pemahaman Weberian, Alfred Schutz dan Peter L. Berger. ${ }^{12}$

\footnotetext{
menambahkan konsep motive tersebut dengan because motive. Malcom Water, Modern Sociological Theory (London: Sage Publication 1994).

${ }^{11}$ H.B. Sutopo, Telaah Karya Penelitian, Sumbangsih Jurnal Penelitian, Universitas sebelas Maret, No 1 Tahun IV (1988), 19

${ }^{12}$ Ketiga tokoh ini menawarkan apa yang disebut dengan in order to motive model Weber, because motive model Schutz dan hingga pragmatic motivePeter L. Berger
} 


\section{Pembahasan}

\section{Peran Ma'had Jämi'ah dalam Menguatkan Tujuan Akademik}

Perguruan Tinggi haruslah memposisikan dirinya sebagai wahana untuk melakukan pencerdasan, transformasi sosial, dan transmisi budaya melalui pengamalan Tri Dharmanya, yaitu pendidikan, penelitian dan pengabdian kepada masyarakat. Perlu ditekankan bahwa Perguruan Tinggi harus menjadi ladang penyemaian ilmu yang berbasis karakter positif dan kearifan lokal bagi masyarakat. Perguruan Tinggi bukanlah sekedar pabrik gelar yang hanya menghasilkan lulusan yang bertitel, melainkan hal yang paling penting adalah bagaimana mencetak alumni yang berkarakter.

Begitu pula halnya dengan adanya 2 Perguruan Tinggi Islam besar yang ada di Jawa-Timur yang juga terus berusaha membuat program-program unggulan dengan tujuan untuk menciptakan generasi muda berilmu pengetahuan yang luhur dan juga memiliki karakter kepribadian mulia yang berlandaskan ajaran agama Islam. Perguruan Tinggi tersebut adalah Universitas Islam Negeri Sunan Ampel Surabaya (UINSA) dan Universitas Islam Negeri (UIN) Maulana Malik Ibrohim yang berlokasi di Malang

Dalam upaya mencapai tujuan tersebut, civitas akademika yang ada dalam struktural dua perguruan tinggi tersebut merancang sebuah program untuk mengembangkan dan meningkatkan kualitas serta kuantitas generasi muda yang memiliki karakter kepribadian Islami. Salah satu program prioritas dan unggulan yang sedang dicanangkan adalah program khusus ditujukan bagi mahasiswa baru yang bertujuan untuk melahirkan calon-calon sarjana serta generasi-generasi bangsa dan agama yang cerdas serta berakhlak mulia, selain sebagai pusat belajar dan mengajarkan ilmu pengetahuan, juga memberikan pembinaan karakter Islami. Dengan adanya program Ma'had al-Jāmi'ah ini diharapkan mampu membangkitkan karakter/budi pekerti mahasiwa yang islami, kuat, dan terhindar dari segala bentuk penyimpangan-penyimpangan perilaku yang dapat mencoreng nama baik pribadi, keluarga maupun instansi serta bangsa ataupun negara.

Dalam hal inilah Peran Ma'had al-Jämi'ah dalam menguatkan tujuan akademik dalam kampus adalah tercermin dalam aktifitas keseharian.Kegiatan ini bertujuan sebagai pembiasaan dan juga sebagai strategi, keteladanan, dan juga menumbuhkan kedisiplinan dan membangun karakter toleran.Sebagaimana disebutkan sebelumnya, keberadaan pesantren kampus, bukan saja bertujuan untuk memperkuat capaian akademik mahasiswa, khususnya mahasiswa baru. Tapi, dalam rangka memperkuat basis nilai-nilai moderat dan toleran. Ini yang kemudian dimaksud sebagai gerakan perkuat ideologi anti radikalisme dari kampus. Adapun kegiatan yang dimaksud adalah:

Pertama, pembiasaan yang baik sebagai sebuah metode. Pembentukan karakter diyakini perlu dan sangat penting untuk dilakukan oleh seluruh lembaga pendidikan, tidak terkecuali di UIN Sunan Ampel Surabaya, lebih spesifik lagi adalah di Ma'had al-Jämi'ah itu dapat menjadi sebuah kebiasaan. Tumbuh dan berkembangnya karakter yang baik akan mendorong seornag mahasantri tumbuh dengan kapasitas dan komitmennya untuk melakukan berbagai hal yang baik, melakukan segalanya dengan benar dan memiliki tujuan hidup. Seorang praktis pembiasan yang baik merupakan sabuah metode yang tepat untuk diaplikasikan dalam lingkungan Ma'had al-Jämi'ah dalam membentuk karakter mahasantri. Di satu sisi menjadi tugas berat para pengasuh, muwajjihmuwajjihah untuk senantiasa membiasakan kebiasaan baik.

Kedua, pembiasaan untuk melaksanakan shalat tahajjud. Aktifitas Mahsantri di Ma'had alJāmi'ah sangatlah padat. Akan tetapi menjadi agenda rutin yang sudah terjadwal dalam keseharian, yaitu berupa shalat tahajjud pada pukul 03.00 dini hari. Pembiasaan bangun di pagi hari sebelum 
shubuh mempunyai manfaat yang luar biasa. Usaha yang dilakukan oleh Muwajjih-muwajjihah yang dalam kesehariannya sebagai pendamping serta pembimbing mahasantri selama 24 jam di Ma'had al-Jāmi'ah adalah dengan membangunkan mahasantri melalui media pengeras suara, diiringi dengan memutar CD atau Kaset Alqur'an, dengan demikian mahasantri akan terbangun setelah mendengar suara keras tersebut. Usaha lain yang dilakukan oleh muwajjih-muwajjihah adalah bekerjasama dengan Dewan Mahasantri untuk membangunkan secara door to door keliling dan masuk ke masing-masing kamar mahasantri. ${ }^{13}$ Supaya lebih mudah mengenal setiap mahsantri yang tinggal dan nyantri di Ma'had al-Jämi'ah, para muwajjih-muwajjihah membuat sistem perwalian terhadap masing-masing mahasantri. Selain memudahkan koordinasi, juga mahasantri merasakan keberadaan para Muwajjih-muwajjihah. Pembiasaan diri terhadap mahasantri untuk bangun malam dan melaksanakan shalat tahajjud, akan berdampak pada kepribadian mahasantri sendiri secara individu dan diharapkan akan membentuk kebiasaan yang baik, lebih mendekatkan diri kepada Sang Pencipta, menjadi pribadi yang santun, rendah hati, tidak sombong, jujur, karena kita merasa menjadi manusia yang lemah. Diharapkan dengan mahasantri melakasanakan kebiasaan bangun dan melaksanakan shalat malam akan membentuk pribadi-pribadi yang mulia di sisi Allah SWT. ${ }^{14}$.

Ketiga, pembiasaan untuk shalat berjamaah. Tidak kalah pentingnya adalah Ma'had al-Jāmi'ah melaksanakan pembiasaan kepada mahasantrinya untuk melakukan shalat berjama'ah. Namun karena mempunyai komitmen yang sama akhirnya kebiasaan tersebut juga bisa dilaksanakan dengan baik. Adapun usaha yang dilakukan para Muwajjih dan Muwajjihah adalah mewajibkan mahasantri untuk shalat berjamaah pada waktu-waktu tertentu, di antaranya adalah shalat Maghrib, Isya' dan Shubuh. Waktu-waktu yang dipilih tersebut dirasa lebih bisa dilakukan daripada waktuwaktu yang lain, karena di luar waktu tersebut para mahasantri beraktivitas di fakultas masingmasing. Di samping dibarengi dengan kegiatan-kegiatan atau aktivitas rutin, di antaranya setelah shalat Maghrib seluruh mahasantri harus mengikuti kegiatan pembelajaran malam, dilanjutkan shalat Isya' yang dilaksanakan setelah usai pembelajaran malam. Waktu shubuh adalah waktu yang cukup efektif bagi Ma'had al-Jämi'ah untuk melaksanakan pembimbingan khususnya program bahasa dengan memberikan kosa kata atau mufrodat baru. ${ }^{15}$

Dengan pembiasaan untuk melaksanakan shalat berjamaah tersebut diharapkan setiap mahasantri lebih saling mengenal antara satu dengan yang lain, terjalin hubungan emosional yang rekat di antara mahasantri, serta membentuk pribadi yang suka berbuat baik, dan mampu untuk mencegah serta menjauhi dari segala sesuatu yang jelek dan tidak ada manfaatnya.

Keempat, pembiasaan doa bersama, dan khotmil qur'an. Kegiatan lainnya yang dibiasakan di Ma'had al-Jāmi'ah adalah melakukan doa bersama, dan Khotmil Qur'an secara rutin pada minggu ketiga yang dilaksanakan setiap 1 (satu) bulan sekali. Banyak manfaat yang diambil dari kegiatan tersebut di antaranya adalah, menumbuhkan rasa kebersamaan dan menepis individualism. Kegiatan tersebut dilaksanakan di masing-masing Ma'had al-Jämi'ah, putra dan putri sendiri-sendiri, yang dilaksanakan seluruh komponen yang ada di Ma’had al-Jämi'ah, mulai dari Kepala pusat,

\footnotetext{
${ }^{13}$ Hasil wawancara dengan Ust. Bahrul Ulum, SS., M.Pd.I salah satu Muwajjih atau Pembimbing mahasantri di Ma'had Putra, pada tanggal 15 September 2018.

${ }^{14}$ Hasil wawancara Bahtiyar Rifa'I, M.Pd.I, Koordinator Bidang Ma'had Putra dan Putri UIN Sunan Ampel Surabaya, pada 9 Oktober 2018.

${ }^{15}$ Data tersebut diproleh dari hasil wawancara dengan Ust. Bahrul Ulum, SS, Salah satu Mmuwajjih di Ma'had al-Ja>mi'ah Puta, pada tanggal 15 September 2018.
} 
Pengasuh, Muwajjih-Muwajjihah dan seluruh mahasantri. Di samping menumbuhkan rasa kebersamaan juga membentuk pribadi yang shalih dan qur'ani yang menjiwai dan mengamalkan nilai-nilai yang terkandung di dalam kitab suci Alqur'an. ${ }^{16}$ Darinya diharapkan nalar keislaman mahasiswa.

Kelima, pembiasaan untuk melaksanakan kegiatan Ta'lim Ma'had. Kegiatan selanjutnya yang secara rutin sekaligus terprogram di Ma'had al-Jami'ah adalah Ta'lim Ma'had. Ta'lim Ma'had adalah program yang popular dengan istilah Program Peningkatan Kompetensi Keagamaan Mahasiswa (P2KKM). Ta'lim Ma'had dilaksanakan pada hari Selasa dan Kamis pada sore hari tepatnya pukul 16.15 s.d. 17.30 WIB. Ta'lim Ma'had diampu oleh para tutor yang berkompeten yang mayoritas sudah menyelesaikan Program Pascasarjana, bahkan banyak dari mereka yang alumnus dari luar negeri seperti Al-Azhar Mesir, Sudan, dan Cape Town Afrika Selatan. ${ }^{17}$ Sudah dijelaskan sebelumnya bahwa Ta'lim Ma'had menjadi kegiatan inti dalam proses pembinaan karakter dan akhlaq untuk mahasantri/mahasiswa. Dalam Ta'lim Ma'had tutor diharapkan dapat menyelipkan nilai-nilai moral dan karakter di sela-sela mereka mengajar.

Di samping Ta'lim Ma'had bertujuan membentuk karakter mahasantri di Ma'had al-Jämi'ah, juga membudayakan budaya ilmiah dan menambah wawasan keislaman, karena mahasantri yang diajarkan adalah materi-materi keislaman. Dengan demikian di samping mahasantri memperaktikkan ilmu yang diperolehnya di kelas dalam kehidupan sehari-hari, juga menjadi bekal mereka untuk terjun di masyarakat setelah lulus dari UIN Sunan Ampel.

Dalam pelaksanaan pembiasaan-pembiasaan yang rupa, tetap saja masih ada hambatan, kendala yang dialami oleh Ma'had al-Jämi'ah meskipun banyak bias diatasi dan diminimalisir. Adapun hambatan dan kendala yang dihadapi oleh ma'had dalam melaksanakan pembiasaanpembiasaan tersebut diantaranya: (1) Kesadaran individu mahasantri yang belum maksimal. Artinya pada saat kegiatan pembiasaan yang sudah terjadwal dan sudah disosialisasikan kepada seluruh mahasantri, masih saja ada beberapa mahasantri yang izin dan tidak mengikuti program tersebut dengan banyak alasan. (2) Latar belakang mahasantri yang berbeda-beda. Maksudnya ada beberapa mahasantri yang masih sangat awam dan belum terbiasa untuk melaksanakan pembiasaanpembiasaan tersebut, namun itu tidak menjadi kendala atau hambatan yang besar, sekadar membutuhkan waktu untk pembiasaan beberapa kali sehingga selanjutnya sudah terbiasa.

Keenam, keteladanan keseharian. Budaya yang diajarkan dalam komunitas Ma'had al-Jāmi'ah atau pesantren di antaranya adalah budaya keteladanan dari seorang kiai atau pimpinan pondok pesantren. Seorang kiai dalam sebuah pesantren atau ma'had sangat besar pengaruhnya terhadap pertumbuhan dan perkembangan pribadi para mahasantri. Keteladanan ini memiliki peran dan fungsi yang sangat penting dalam membentuk keperibadian seseorang, guna menyiapkan dan mengembangkan Sumber Daya Manusia (SDM), serta menyejahterakan masyarakat, kemajuan negara, dan bangsa. ${ }^{18}$

Tidak jauh berbeda dengan keadaan yang ada di Ma'had al-Jāmi'ah, meskipun secara struktur dipimpin oleh seorang direktur, namun budaya yang terbentuk adalah direktur setara dengan keberadaan kiai dalam dunia pesantren.

${ }^{16}$ Data diperoleh dari hasil wawancara dengan Dr. Wasid, SS., M.Fil.ISekretaris Ma'hadUIN Sunan Ampel Surabaya, pada tanggal 20 Oktober 2018.

${ }^{17}$ Ibid.

${ }^{18}$ Data diperoleh dari hasil wawancara dengan Drs. H. Abdul Mujid Adnan, M.Ag Kepala Pusat Ma'had alJami'ahUIN Sunan Ampel Surabaya, pada tanggal 20 Oktober 2018. 
Kepemimpinan Direktur Ma'had al-Jāmi'ah terkesan seperti seorang kiai dalam dunia pesantren. Meskipun tidak menetap dan tinggal di dalam ma'had, namun di setiap kesempatan ketika menyampaikan sambutan dan motivasinya kepada seluruh mahasantri bahwa beliau memberikan sebuah keteladanan untuk senantiasa memperbanyak membaca, menulis, bahkan untuk terus melanjutkan studi sampai tingkat yang paling akhir. Di samping keteladanan untuk studi, Direktur ma'had juga memberikan keteladanan kepada mahasantri untuk senantiasa berkarya dalam bentuk apa pun, di antaranya tulis menulis, mengarang buku, keterampilan berupa soft skill dan lain sebagainya.

Peran dari para Muwajjih-Muwajjihah juga sangat penting di dalam memberikan sebuah keteladanan kepada mahasantri. Karena merekalah yang mendampingi mahasantri selama 24 jam di ma'had. Para muwajjih-muwajjihah senantiasa memberikan bimbingan, suri tauladan kepada mahasantri memberikan contoh kebiasaan yang baik kepada mereka mulai dari bangun malam untuk melaksanakan shalat tahajjud, shalat berjamaah, menggunakan bahasa dalam percakapan, dan lain sebagainya.

Motivasi untuk senantiasa belajar sudah dicontohkan oleh para muwajjih-muwajjihah terbukti bahwa seluru dewan muwajjih-muwajjihah adalah mahasiswa yang sedang melanjutkan studinya pada program Pascasarjana di UIN Sunan Ampel Surabaya, di samping juga mempunyai peran di Ma’had al-Jāmi'ah. Keteladanan untuk bersikap mandiri, tidak mudah putus asa, dan lain sebagainya.

Dalam pada itu, keteladanan keseharian di Ma'had al-Jämi'ah juga diwujudkan melalui kajian rutin kitab kuning setiap hari Senin, Selasa dan Rabu. Kitab yang dikaji adalah kitab Fathul Qorib, Risalah Ahlus Shunnah Wal-Jama'ah dan Tafsir Hamami. Dalam kitab tersebut banyak sekali dibahas bagaimana membentuk seorang pribadi yang shalih, pribadi yang santun, dan pribadi yang bisa memberikan manfaat kepada orang lain. Bahkan dalam kitab tersebut diajarkan bagaimana seseorang berproses untuk menjadi seorang sufi. Oleh karenanya, diharapkan dari kajian kitab tersebut mahasantri lebih bisa mengambil hikmah dan pelajaran penting untuk diaplikasikan dalam kehidupan sehari-hari.

Ketujuh, menumbuhkan kedisiplinan. Dalam kultur pesantren, pembiasaan disiplin telah ada dan berproses sesuai dengan maksud berdirinya. Keseharian kultur pesantren mulai pagi, bahkan jelang waktu shubuh, hingga tengah malam telah dilakukan kegiatan yang sangat padat, dari kegiatan shalat tahajjud, shalat berjamaah hingga mengaji kitab kuning bersama para guru. Kegiatan ini dilakukan secara rutin kecuali masa-masa libur, seperti hari Jum'at. Model ini yang kemudian pesantren memiliki karakter sendiri membedakan pendidikan lainnya. ${ }^{19}$

Dari realitas ini, maka pendidikan karakter salah satu tujuan pokoknya adalah terbangunnya karakter peserta didik yang disiplin pada diri sendiri, sikap disiplin kelak akan melatih mereka untuk mandiri. Santri yang disiplin dimungkinkan akan terlatih bagaimana mengelola kenyataan sesuai dengan kemampuan yang dimiliki. Sebaliknya, mereka yang tidak disiplin akan berpengaruh pada kenyataan hidupnya, khususnya dalam menyikapi problem kehidupan.

Ma'had al-Jāmi'ah sebagai salah satu pilar institusi di lingkungan kampus UIN Sunan Ampel memiliki tujuan tersebut, yaitu adanya mahasantri yang berdisiplin tinggi. Mahasantri yang disiplin akan mempermudah proses pembinaan karakter yang dicanangkan oleh Ma'had al-Jämi'ah sesuai

${ }^{19}$ Tentang tradisi pesantren baca Zamakhsyari Dhofier, Tradisi Pesantren: Studi Pandangan Hidup Kyai dan visinya Mengenai Masa Depan Indonesia (Jakarta: LP3ES, 2011); Ridlwan Nasir, Mencari Tipologi Format Pendidikan Ideal (Yogyakarta: Pustaka Pelajar, 2005). 
dengan jadwal dan waktu yang telah ditentukan dari mulai subhuh hingga malam hari. Pada tahapan selanjutnya kedisiplinan yang diharapkan akan berpengaruh pada prilaku mahasantri, ketika mengikuti perkuliahan reguler.

Adapun kegiatan-kegiatan di lingkungan Ma'had al-Jāmi'ah tidaklah berorientasi pada kecerdasan pikiran semata, apalagi mahasantri pada siang hari ditempa pada proses pendidikan model kampus yang mengutamakan arus akademik yang rasional, tapi juga pada pembinaan karakter melalui pelatihan kedisiplinan. Artinya, tidak melulu pesantren mahasiswa ini berkonsentrasi pada penguasaan bahasa asing (Arab/Inggris) pada mahasantri, tapi juga pada pembinaan untuk disiplin.

Misalnya, setelah shalat shubuh diisi dengan kegiatan pembinaan bahasa, tepatnya pengenalan dan penguasaan kosa kata baru, khususnya bahasa Arab dan Inggris. Kenapa dilaksanakan waktu pagi, bukan hanya disebabkan faktor tidak adanya waktu yang tersedia, tapi lebih dari itu, mahasantri dilatih untuk meyakini bahwa sukses, salah satu kuncinya adalah keuletan dan kedisiplinan.

Hal senada dengan wawancara penulis dengan salah satu Muwajjih dan Muwajjihah ${ }^{20}$ Ma'had $^{\prime}$ al-Jāmi'ah $h$ yang setiap harinya atau 24 jam mengawal dan membimbing mahasantri, sebagai berikut: "Begini Mas, kegiatan șhabah al-lughah adalah salah satu metode untuk melanjutkan terwujudnya visi dan misi umum Ma'had al-Jami'ah, yaitu penguasaan bahasa asing. Sesuai dengan namanya, kegiatan ini dilakukan pada pagi hari, agar mahasantri terbiasa disiplin sejak dini." ${ }^{21}$ Dengan pembiasaan adanya kegiatan positif di pagi hari, para mahasantri ditumbuhkan karakter tidak ada jalan pintas menuju sukses. Semua butuh kerja keras, di samping doa. Karenanya, dengan kedisiplinan itu, mahasantri memiliki komitmen untuk menjadikan keseharian itu dalam kerangka nilai-nilai positif, dan semaksimal mungkin mengurangi hal-hal yang negatif yang sejatinya merusak karakter dirinya dan bertantangan dengan tujuan dibentuknya di lingkungan kampus UIN Sunan Ampel dan UIN Maulana Malik Ibrahim Malang.

Proses kedisiplinan karakter ini juga berlaku pada malam hari melalui pembelajaran malam yang didampingi oleh beberapa dosen yang mempunyai kemampuan bahasa Inggris dan Arab. Mahasantri diwajibkan mengikuti kegiatan ini termasuk kajian kitab kuning yang dilaksanakan setiap hari Senin, Selasa dan Rabu.

Untuk menopang tujuan karakter disiplin itu, pengurus menyediakan presensi kehadiran. Setidaknya presensi ini sebagai landasan awal agar mahasantri disiplin, sekalipun pada awalnya merasa dipaksakan, dikarenakan mahasantri sejak siang hari sudah melakukan proses pendidikan reguler di Fakultasnya masing-masing.

Proses menciptakan karakter disiplin bagi mahasantri bukanlah pekerjaan yang mudah apa lagi yang tinggal di Ma'had al-Jāmi'ah berasal dari budaya dan sosial yang berbeda-beda. Keterlibatan pengurus, Muwajjih dan mahasantri adalah kunci sukses dalam membangun karakter disiplin.

Model partisipatif dengan pelibatan semua unsur mengantarkan karakter disiplin itu berjalan dengan tidak paksaan. Disiplin pada akhirnya dibutuh kesadaran diri, tapi peran pengurus dan Muwajjih adalah melakukan langkah penggingatan hingga peringatan. Hal tersebut yang menjadi kendala para Muwajjih-Muwajjihah dalam menumbuhkan kedisiplinan terhadap mahasantri, masih

\footnotetext{
${ }^{20}$ Istilah musyrif atau musyrifah adalah sebuah sebutan pembimbing yang ada di lingkungan $\mathrm{Ma}$ 'had al$J a>m i$ 'ah. Model pilihannya adalah seleksi yang dilakukan oleh pengurus, berdasarkan pada kemampuan mereka dalam bahasa asing (Arab atau Inggris).

${ }^{21}$ Data ini diperoleh dari hasil wawancara pada tanggal 15 Juni 2018 dengan Bahrul Ulum.
} 
saja ada beberapa mahasantri yang sangat susah untuk berlaku disiplin. Memang faktornya cukup banyak, salah satu diantaranya adalah masih belum terbiasa dengan hal kedisiplinan. Sehingga masih belum bisa berlaku disiplin dan mungkin masih kaget dengan budaya tersebut. Meskipun demikian usaha para pengelola, Muwajjih-Muwajjihah dan semua stakeholder akan terus dilaksanakan sampai sluruh mahasantri bisa terbiasa untuk disiplin.

Kedelapan, membangun karakter toleran. Dalam kehidupan social, keragaman manusia adalah Sunnatullah. Artinya, sekalipun Tuhan berkuasa, yang kuasanya tidak bisa di interversi oleh siapapun, untuk menjadikan semua manusia dalam satu warna, tapi kenyataan Dia tetap menjadikan manusia beragam. Keragaman ini sebenarnya wujud keesaan-Nya yang tidak bisa ditandingi.

Oleh karena itu, sekalipun berbeda tidak alasan seseorang untuk tidak menghormati dan bersikap toleran kepada yang lain apalagi perbedaan ini adalah kehendak-Nya. Mengutip perkataan M. Fathullah Gule, aktivis perdamaian dari Turki, mengatakan "meskipun kita pada dasarnya tidak memiliki pemikiran yang sama, tapi kita sama hidup dalam dunia yang sama". ${ }^{22}$ Jadi karena kesamaan tinggal di dunia, maka antar sesama memiliki tanggung jawab untuk yang menjaga yang lain.

Jika dikaitkan dengan pendidikan karakter, maka karakter yang diharapkan dari peserta didik adalah tumbuhnya rasa penghargaan terhadap yang berbeda dan memiliki sikap toleransi. Perbedaan harus menjadi modal utama membangun kebersamaan dengan menumbuhkan sikap toleran kepada yang lain.

Kultur yang beragam nampaknya sejak awal ada dalam lingkungan Ma'had al-Jāmi'ah baik yang berasal dari ram jurusan, program maupun keragaman asal usul daerah maupun Negara. Artinya, mahasantri yang tinggal di Ma'had al-Jämi'ah memiliki perbedaan, bahkan perbedaan itu laksana miniatur Indonesia sebab mahasantri yang tinggal di Ma'had al-Jāmi'ah adalah keterwakilan dari daerah-daerah seluruh Indonesia.

Melihat kenyataan itu, dalam lingkungan Ma'had al-Jämi'ah ditegaskan sejak awal agar mahasantri yang tinggal tidak dalam satu daerah yang terdiri dari empat orang atau lebih bergantung pada luas kamar yang dihuni. Untuk tujuan ini, pengurus meng-intervensi sejak dini dengan menempatkan mereka secara beragam dalam satu kamar. Harapannya agar mahasantri memiliki karakter luhur dengan menghargai segala perbedaan dan mengurangi rasa primordial asal usul dirinya.

Pendidikan karakter mahasantri tidak mungkin terbentuk begitu saja tanpa melibatkan semua pihak di Ma'had al-Jāmi'ah. Mahasantri yang memiliki latar belakang yang berbeda bila dibiarkan bukan hanya memunculkan sikap primordial atas dasar program maupun kesukuan, tapi lambat laun akan mengancam keberlangsungan kegiatan lain yang mengarah pada proses pembentukan karakter. Jika dilihat dari tiga siklus pendidikan karakter yang dikembangkan oleh Thomas Lickona ${ }^{23}$, yaitu pengetahuan moral, perasaan moral dan tindakan moral, dalam lingkungan Ma'had al-Jämi'ah mengalami proses demikian. Artinya, pendidikan karakter yang diamankan tidak lain bertujuan peningkatan moralitas mahasantri sebagai anak didik. (1) Pengetahuan moral. Mahasantri sekali lagi sejak awal diberikan pemahaman agar tidak tinggal dengan mereka yang memiliki asak usul yang sama. Mahasantri yang berasal dari program tertentu, tidak tinggal sekamar dengan program yang sama. Pengetahuan ini memungkinkan mahasantri memahami betul bahwa perbedaan halam

\footnotetext{
${ }^{22}$ M. Fethullah Gulen, Cinta dan Toleran (Tangerang: Bukindo Erakarya Publishing, 2011), 45.

${ }^{23}$ Lihat penjelasa Thomas Lickona dalam bukunya: Mendidik untuk Membentuk Karakter: Bagaimana Sekolah dapat Menhajarkan Sikap Hormat Tanggung Jawab (Jakarta: Bumi Aksara, 2013), 85-99.
} 
kehidupan tidak harus berbeda dalam mengakses nilai-nilai kemanusiaan, misalnya jujur dan berkeadilan pada diri sendiri sekaligus pada yang lain. Dengan pengetahuan yang matang tentang perbedaan itu, mahasantri akan terbiasa melihar perbedaan sebagai hal yang biasa. Pengetahuan akan melahirkan karakter tertentu, sebaliknya kekurangtahuam seseorang pada hakekat perbedaan memungkinkan munculnya sikap promordial, yang ujung-ujungnya mudah mengulut konflik. (2) Perasaan moral. Dalam konteks ini mahasantri ditanamkan nilai-nilai emosional bahwa hidup di dunia tidaklah dihuni oleh satu kelompok, tapi juga oleh kelompok yang beragam. Dengan emosional ini karakter mahasantri tumbuh dan sadar bahwa kesempurnaan hidup seseorang juga didukung kesempurnaan yang lain. Artinya, tindakan kekerasan yang dilakukan terhadap orang lain sebenarnya juga merusak nilai-nilai luhur kemanusiaan dirinya sendiri sebab hakekatnya semua manusia mendambakan hidup harmoni dalam kedamaian. Dengan pengetahuan yang baik tentang perbedaan dan adanya perasaan emosional yang tinggi menyikapi perbedaan di lingkungan Ma'had al-Jämi'ah sedikit demi sedikit akan mempengaruhi karakter mahasantri untuk sadar diri. Alasannya, memang pegetahuan perbedaan tidak cukup sebagai modal penumbuhan karakter toleran, tanpaa didukung sikap emosional mahasantri. Sikap emosional tentang hakekat hidup dan menyadari bahwa dirinya bagian dari orang lain jika tumbuh dalam benak mahasantri akan memunculkan sikap toleran. (3) Tindakan moral. Dalam lingkungan Ma'had al-Jami'ah secara keseharian berbeda dengan para mahasiswa yang tinggal di kampus. Ada proses pengawasan dalam stiap hari, sehingga mahasantri kelak memiliki tanggung jawab bukan saja pada dirinya tapi juga tanggung jawab sosial. Tindakan bermoral dalam konteks isu-isu keragaman mahasantri adalah munculnya sikap menghormati dan prilaku toleran setiap hari. Mahasantri dalam setiap kegiatan tidak terlihat asalusul seseorang, tapi melihat aspek manfaat kegiatan yang ada di lingkungan Ma'had al-Jami'ah.

Sementara itu pengurus-utamaan dilanjutkan dengan proses pembinaan yang dilakukan para Muwajjih-Muwajjihah bertanggung jawab memberikan peneladanan. Peneladanan karakter toleran nampaknya dianggap penting sehingga tidak memunculkan kontradiksi cara pandangan yang dialami mahasantri, misalnya ada anjuran sikap toleran tapi kenyataan di lingkungan Ma'had alJami'ah para pembina tidak memberikan teladan yang baik.

Penumbuhan karakter mahasantri agar bersikap toleran dalam lingkungan yang berbeda adalah modal tersendiri bagi Ma'had al-Jami'ah bagaimana menanamkan sikap menghargai perbedaan dan prilaku, apalagi pesantren model kampus ini berada dalam lingkungan kota Surabaya, kota metropilitan kedua setelah ibu kota Jakarta.

\section{Kontruksi Idiologis $M a$ 'had al-Jāmi'ah dalam Pengarusutamaan Islam moderat}

Gagasan untuk memunculkan jiwa dan semangat Islam moderat kiranya mendapatkan momentum yang tepat saat gerakan Keagamaan transnasional itu mulai menancapkan ideologinya melalui lembaga-lembaga pendidikan (Ma'had al-Jämi'ah) yang mereka dirikan. Sebagaimana teori konstruksivitas didefinisikan sebagai pembelajaran yang bersifat generatif, yaitu suatu tindakan yang mencipta suatu makna dari apa yang dipelajari. Apa yang dilalui selama di Ma'had alJämi'ah merupakan wadah, himpunan dan pembinaan pengalaman demi pengalaman dalam kehidupan sehari-hari. Hal ini menjadikan mahasantri mempunyai, memiliki pengetahuan yang baik dan menjadikan dirinya lebih dinamis dalam melihat realitas yang dihadapinya.

Untuk menentukan suatu lembaga pendidikan Islam berideologi Islam Moderat adalah menurut Masdar Hilmy memiliki ciri-ciri (1) menganut ideologi non-kekerasan dalam menyebarkan Islam; (2) mengadopsi cara hidup modern dengan semua turunannya, termasuk ilmu pegetahuan, 
teknologi, demokrasi, hak asasi manusia, dan sejenisnya. Kemudian (3) cara berfikir rasional; (4) pendekatan kontekstual dalam memahami Islam; (5) penggunaan ijtihad untuk membuat pendapat hukum dalam kasus yang tidak ada pembenaran secara eksplisit dalam Alqur'an dan Sunnah; dan (6) memiliki sikap-sikap: toleran, harmoni, dan kerja sama di antara kelompok-kelompok agama yang berbeda.

Berikut adalah sejumlah kegiatan dalam rangka mewujudkan sikap muslim yang moderat di dalam Ma'had al-Jāmi'ah. Toleransi budaya melalui pembinaan kehidupan bermahasiswa yang toleran, memahami keanekaragaman budaya dan lebih lagi menghaergai hakikat manusia tanpa memandang status sosial maupun ekonomi. Tahun pertama perkuliahan adalah tahun awal dimana mahasiswa berada dalam proses transisi dan pencarian jati diri serta kebebasan. Masa ini menjadi peranan penting untuk mengarahkan mahasiswa ke arah yang benar. Mahasantri (mahasiswa Ma'had al-Jämi'ah) adalah mahasiswa yang berasal dari berbagai latar belakang budaya dan pola pikir yang berbeda sehingga membutuhkan waktu bagi mahasiswa untuk beradaptasi dengan budaya lain tujuannya adalah saling mengenal dan menerima perbedaan yang ada serta pengenalan lingkungan budaya kampus di perguruan tinggi. Pola kehidupan yang dilakukan adalah dalam rangka menyamakan persepsi dan pola pikir yang berbeda-beda. Kegiatan pola kehidupan di Ma'had al-Jāmi'ah mencakup kemampuan manajemen antara lain manajemen diri, manajemen waktu, kehidupan sosial dan ketrampilan belajar serta potensi kognitif serta kemampuan berbahasa baik bahasa Arab maupun bahasa Inggris.

Hidup bersama dengan orang yang baru dikenal tidaklah mudah, model hidup bersama di Ma'had al-Jämi'ah model yang diberikan kepada mahasiswa ke ranah yang lebih luas sebagai komunitas yang plural, menerima diri sendiri dan orang lain adalah langkah awal memulai kehidupan bermasyarakat yang baik. Konflik bisa saja muncul dalam keragaman.Srtategi menempatkan mahasantri Ma'had al-Jämi'ah pada masing-masing kamar dengan mengacak berbagai latar belakang baik bahasa, budaya, sosial, ekonomi maupun intelektualnya merupakan model kehidupan berkelompok yang diterapkan di Ma'had al-Jāmi'ah. Di samping itu mahasiswa sekaligus juga belajar saling menghargai dan menerima nilai-nilai budaya lain yang berbeda dengan budayanya. Pola pembinaan yang dilakukan oleh Ma'had al-Jämi'ah juga menunjukkan peranan penting dalam menanamkan jiwa Islam moderat yakni dilakukannya pembinaan akidah, penguatan nilai-nilai ke-Islaman dan dilakukannya pembinaan karakter serta penguatan kebahasaan. Pembinaan dilakukan melalui sejumlah kegiatan atau langsung bentuk perbuatan-perbuatan yang mencerminkan karakter terpuji seperti kajian bulanan, kajian mingguan, pertama; dalam bentuk pola peribadatan yaitu sholat berjamaah, sholat tahajud, kegiatan membaca sholawat Nabi, Burdah, Berjanji dan diba'an serta menghafal surat-surat pendek al-Qur'an. Kedua; pola pendidikan yaitu kajian-kajian rutin tafsir tematik al-Qur'an, kitab Bidayah Wa Hinayah, kitab Adabul Mu'alimin dan kajian rutin kitab fiqh wanita. Ketiga; pola kebahasaan dan terakhir atau keempat; pola pergaulan dan interaksi. Kegiatan yang dilakukan dalam lingkungan Ma'had al-Jāmi'ah memiliki mimpi besar untuk tetap mengawal agar dua kampus ini mampu melahirkan alumni-alumni yang berkomitmen pad nilai-nilai moderat dan toleran. Karenanya, ragamnya kegiatan di dua kampus ini bukanlah harga mati, tapi hanya tawaran model pembinaan yang sangat mungkin dilain tempat akan mengalami perbedaan.

Komitmen pada penguatan ini pastinya tidak lepas adanya keterlibatan semua pihak, baik di internal Pusat Ma'had al-Jāmi'ah di UIN Sunan Ampel dan UIN Maulana Malik Ibrahim. Karenanya, 
penguatan selalu dilakukan di dua kampus ini dalam rangka melakukan pembinaan pada mahasiswa yang tinggal di asrama, termasuk juga mahasiswa yang tidak tinggal di asrama.

\section{Kesimpulan dan Saran}

Salah satu program prioritas dan unggulan yang sedang dicanangkan adalah program khusus Ma'had al-Jāmi'ah di UIN Sunan Ampel Surabaya dan UIN Maulana Malik Ibrahim diperuntuhkan bagi mahasiswa baru yang bertujuan untuk melahirkan calon-calon sarjana serta generasi-generasi bangsa dan agama yang cerdas serta berakhlak mulia, selain sebagai pusat belajar dan mengajarkan ilmu pengetahuan, juga memberikan pembinaan karakter Islami. Dengan adanya program Ma'had al-Jāmi'ah ini diharapkan mampu membangkitkan karakter/budi pekerti mahasiwa yang Islami, kuat, dan terhindar dari segala bentuk penyimpangan-penyimpangan perilaku yang dapat mencoreng nama baik pribadi, keluarga maupun instansi serta bangsa ataupun negara. Dalam hal inilah Peran Ma'had al-Jāmi'ah dalam menguatkan tujuan akademik dalam kampus adalah tercermin dalam aktifitas keseharian. Kegiatan ini bertujuan sebagai pembiasaan dan juga sebagai strategi, keteladanan, dan juga menumbuhkan kedisiplinan dan membangun karakter toleran Masa ini menjadi peranan penting untuk mengarahkan mahasiswa ke arah yang benar. Pola pembinaan yang dilakukan oleh Ma'had al-Jämi'ah juga menunjukkan peranan penting dalam menanamkan jiwa Islam moderat yakni dilakukannya pembinaan akidah, penguatan nilai-nilai ke-Islaman dan dilakukannya pembinaan karakter serta penguatan kebahasaan. Pembinaan dilakukan melalui sejumlah kegiatan atau langsung bentuk perbuatan-perbuatan yang mencerminkan karakter terpuji seperti kajian bulanan dan kajian mingguan dalam bentuk pola peribadatan yaitu sholat berjamaah, sholat tahajud, kegiatan membaca sholawat Nabi, Burdah, Berjanji dan diba'an serta menghafal surat-surat pendek al-Qur'an, pola pendidikan yaitu kajian-kajian rutin tafsir tematik al-Qur'an, kitab Bidayah wa Nihayah, kitab Adabul Mu'alimin dan kajian rutin kitab fiqh wanita, pola kebahasaan, dan pola pergaulan dan interaksi. Apapun yang dihasilkan dalam ptulisan ini adalah sebuah proses ilmiah yang menyesuaikan dengan maksud subyek yang dijawab oleh peneliti. Maka saran peneliti, perlu adanya penelitian lain yang fokus mengungkap mengenai tipologi pembinaan mahasiswa di pesantren kampus atau Ma'had al-Jämi'ah.

\section{Daftar Pustaka}

Adiwilaga, Rendi "Puritanisme dan Fundamentalisme dalam Islam Transnasional Serta Implikasinya Pancasila Sebagai Ideologi Bangsa” dalam Journal of Governance, Volume 2, No 1, Juni, 2017.

Ali, As’ad Said. Ideologi Gerakan Paska Reformasi. Jakarta: LP3ES. 2013.

Al-Amin, Ainur Rafiq Proyek Khilafah, Perspektif Kritis. Yogyakarta: LKiS, 20015.

El Fadl, Khaled Abou Selamatkan Islam dari Muslim Puritan. Jakarta: Penerbit Serambi. 2005.

http://www.nu.or.id/post/read/9124/

https://kemenag.go.id/home/artikel/42942.

https://nasional.sindonews.com/read/1189843/18/hasyim-muzadi-dan-fleksibilitas-islam1489973140.

Jamhari dan Jajang Jahroni, Gerakan Salafi Radikal di Indonesia.Jakarta: Rajawali Press. 2004.

Maimunah, "Kepemimpinan Pembelajaran di Pondok Pesantren (Studi Kasus di Ma'had al-Jami'ah IAIN Ambon)" dalam Jurnal Fikratuna, Volume 7, Nomor 2, Juli-Desember 2015. 
Nurrohman dan Marzuki Wahid. "Politik Formalisasi Syari'at Islam dan Fundamentalisme Islam". dalam Jurnal Penelitian Direktorat Perguruan Tinggi Agama Islam. Istiqro'. Vol. 01. No. 01. 2002.

Rahmat, Imdadun. Ideologi Politik PKS; dari Masjid Kampus ke Gedung Parlemen. Yogyakarta: LKiS. 2008.

Sahri, "Radikalisme Islam di Perguruan Tinggi Perspektif Islam" dalam jurnal Hukum dan Perundangan Islam; al-Daulah, Volume 6, Nomor 1, April 2016.

Semin, Manajemen Pendidikan Berbasis Budaya Pesantren dalam Pembentukan Karakter Mahasiswa (Studi atas Ma'had al-Jamiah Ulil Abshar STAIN Ponorogo) (Yogyakarta, Tesis UIN Sunan Kalijaga, 2015).

Sutopo,H.B. Telaah Karya Penelitian, Sumbangsih Jurnal Penelitian, Universitas sebelas Maret, No 1 Tahun IV (1988), 19.

Umar, Rizky Mardhatillah. "Melacak Akar Radikalisme Islam di Indonesia" dalam jurnal Ilmu Sosial dan Ilmu Politik, Volume 14, No 2, November, 2010.

Water, Malcom.Modern Sociological Theory. London: Sage Publication 1994.

Zainiyati, Husniyah Salamah. "Landasan Fondasional Integrasi Keilmuan di UIN Maulana Malik Ibrahim dan UIN Sunan Ampel Surabaya ", dalam Jurnal LP2M UIN Sunan Ampel Surabaya, Penelitian Ilmu-Ilmu Keislaman, Vol. 19, No. 2, 2016.

Ismail, Habib, and Agus Setiawan. "Pemberdayaan Pondok Pesantren Nahdlatul Ulama (NU) Dalam Upaya Deradikalisme Paham Dan Gerakan Islam Radikal Di Kota Metro." Fikri : Jurnal Kajian Agama, Sosial Dan Budaya 3, no. 1 (July 31, 2018): 173-92. https://doi.org/10.25217/jf.v3i1.282.

Mushodiq, Muhamad Agus, Suhono Suhono, Bety Dwi Pratiwi, and Erni Zuliana. "Kristalisasi Ideologi Islam Nusantara Melalui Pembelajaran Dan Pengadaan Kaligrafi.” Fikri : Jurnal Kajian Agama, Sosial Dan Budaya 3, no. 1 (July 31, 2018): 143-72. https://doi.org/10.25217/jf.v3i1.281.

Rahmat, M. Imdadun. Ideologi Politik PKS: Dari Masjid Kampus Ke Gedung Parlemen. Cet. 1. Yogyakarta: LKiS : distribusi, LKiS Pelangi Aksara Yogyakarta, 2008. 